\title{
Richness of Wild Bees (Hymenoptera: Apidae) in a Forest Remnant in a Transition Region of Eastern Amazonia
}

\author{
Luciano André Chaves Ferreira $\mathbb{D}^{1},{ }^{1}$ Denilson Costa Martins $\mathbb{D}^{\mathrm{D}},{ }^{2}$ Márcia Maria Corrêa Rêgo, ${ }^{3}$ \\ and Patrícia Maia Correia de Albuquerque $\mathbb{B D}^{3}$ \\ ${ }^{1}$ Graduate Program in Biodiversity and Conservation, Federal University of Maranhão, São Luís, Maranhão, Brazil \\ ${ }^{2}$ Graduate Program in Biodiversity and Biotechnology in the Legal Amazon-Bionorte, Federal University of Maranhão, \\ São Luís, Maranhão, Brazil \\ ${ }^{3}$ Laboratory for Bee Studies, Department of Biology, Federal University of Maranhão, São Luís, Maranhão, Brazil
}

Correspondence should be addressed to Luciano André Chaves Ferreira; lucianochaves03@gmail.com

Received 8 July 2019; Accepted 10 September 2019; Published 23 October 2019

Academic Editor: Jan Klimaszewski

Copyright (C) 2019 Luciano André Chaves Ferreira et al. This is an open access article distributed under the Creative Commons Attribution License, which permits unrestricted use, distribution, and reproduction in any medium, provided the original work is properly cited.

\begin{abstract}
Eastern Amazonia is an area with great biological diversity that has suffered rapid deforestation and forest fragmentation over the years. Because of the scarcity of data on the fauna and flora, the northwest of the state of Maranhão has become a priority area for studies that seek to gain a better understanding of bee fauna. Between August 2013 and December 2014, in collections at twomonth intervals, a total of 1047 bees belonging to 70 species were collected using two methods (an insect net and scent-baited traps). Apinae was the most abundant subfamily and had the greatest species richness (63 species and 1039 individuals); the most notable tribes in this subfamily were Meliponini (20 species and 445 individuals) and Euglossini ( 24 species and 452 individuals). In all, $62.8 \%$ of the total richness was sampled with an insect net and $34.2 \%$ with bait traps. Bees were present in every collection month, and August and December were the months with the greatest richness and abundance, respectively. Although the species accumulation curve did not stabilize, the results were positive as three new species were recorded for the Maranhão state: Bombus transversalis (Olivier, 1789); Xylocopa suspecta Moure and Camargo, 1988; and Xylocopa macrops Lepeletier, 1841, and eleven for the Amazonian region of the state.
\end{abstract}

\section{Introduction}

Bees are insects that have a very close relationship with plant species and are undoubtedly the most important pollinators in the majority of biomes where angiosperms are found. They are noteworthy for their species diversity and varied size and behavior [1].

There are estimated to be more than 4,000 genera and around 25,000 species of bees distributed in different regions of the world [2]. Apoidea is currently organized in nine subfamilies, of which five are found in Brazil: Andreninae, Apinae, Colletinae, Halictinae, and Megachilinae [3].

Moure et al. [4] estimated that there are 640 bee species in the state of Maranhão although only 153 recognized species (23\%) are registered in biological collections [5]. This estimate is based primarily on systematic studies that have been carried out in different ecosystems in the state, including flooded fields (Baixada Maranhense) [6], Cerrado (savanna-like grasslands) [7-13], open rainforest [14, 15], dense rainforest [16], and restinga (sandy coastal strips and their characteristic vegetation) [17-20].

The Amazonian region of the state of Maranhão, in the west of the state, has suffered severe environmental impacts over the years that have adversely affected its ecosystem functions and led to a consequent reduction in biological diversity [21]. Currently, less than $25 \%$ of the original vegetation is left [22]. Soares Filho [23] estimated that $97 \%$ of the forest remnants would be lost in the coming 50 years, leading to the complete elimination of the ecological functionality of the region.

Although it has suffered considerable deforestation and forest fragmentation, the Amazonian region of the state of 
Maranhão still has enormous biological richness and aquatic and terrestrial physiognomic habitat types [24, 25]. Nevertheless, the pollinator fauna in the region remains largely unknown [26].

In this context, the speed with which negative impacts are being exerted on natural systems in the Amazonian region of the state of Maranhão and the lack of data on the fauna and flora in the region make this a priority area for studies that seek to gain a better understanding of the bee community in the region $[27,28]$.

One approach that can be adopted for this type of study is a structured inventory. In this type of inventory, periodic samples are taken and used for a variety of analyses of community composition $[29,30]$. Taxonomic identification of bees and identification of their diversity patterns constitute the first steps in the definition of strategies for rational exploitation and conservation of the resources needed by these pollinators $[31,32]$.

In light of the above, the present study sought to analyze the composition of bee fauna in an area of the Amazon forest with the aid of the diversity metrics richness, abundance, and relative frequency.

\section{Materials and Methods}

2.1. Study Area. The study was carried out in easternmost Amazonia on private property extending over 120 ha (Prata Farm, $1^{\circ} 15^{\prime} 0.94^{\prime \prime} \mathrm{S} 46^{\circ} 0^{\prime} 39.94^{\prime \prime} \mathrm{W}$ ) in the municipality of Carutapera in the far northwest of the state of Maranhão (Figure 1).

The predominant local vegetation is dense alluvial rainforest, according to the classification of Veloso et al. [33], with forest formations such as mangroves and alluvial communities (riparian forest) along water courses as well as vines and palm trees on the plains.

Prata Farm is at a low altitude and does not have any steep slopes. The highest points on the farm are around $20 \mathrm{~m}$ above the sea level. The climate is a tropical monsoon climate and is characterized by temperatures that vary little throughout the year [34]. There are two well-defined seasons: the dry season, from July to December, and the rainy season, from January to June. Mean annual temperature and mean annual rainfall are $26.6^{\circ} \mathrm{C}$ and $2100 \mathrm{~mm}$, respectively [35].

The study area is part of the western northeast Atlantic Basin (Gurupi subbasin) and has two permanent water bodies: the Xavier river and the source of the Prata river. It lies within a 15 ha, predominantly closed, native forest fragment considered part of the nonimpacted forest in the region [25], which has undergone widespread deforestation and fragmentation as a result of agricultural and livestockfarming activities.

Collections were performed between August 2013 and December 2014 at two-month intervals, giving a total of eight collections. Two methods were used: active searches with an insect net and scent-baited traps.

2.2. Insect Net. An insect net was used to perform active searches for bees, mainly when they were visiting flowers but also when they were at rest, in flight, or attracted by perspiration [36]. This collection method was used mainly in open areas, where the vegetation consists primarily of bushes, as trees inside the forest fragments are very tall, and most of the flowers are only exposed in the canopy, making them very difficult to reach [37]. Sampling effort with the insect net was $18 \mathrm{~h}$ per collection, from $8 \mathrm{AM}$ to $5 \mathrm{PM}$ over two consecutive days, or a total of $144 \mathrm{~h}$.

2.3. Scent-Baited Traps. For the scent-bait method, traps were made from PET (polyethylene terephthalate) bottles, as proposed by Ramalho et al. [38]. Each trap had three entrances, where bees could get access to methyl cinnamate, eugenol, and eucalyptol, scents widely used in studies on Euglossini bee communities $[39,40]$. The scent was placed in small wads of cotton, which were then put inside the traps (one per trap), and the traps were replenished every hour with two drops of the respective essence. The traps were left in the closed forest approximately $8 \mathrm{~m}$ from each other and $1.5 \mathrm{~m}$ above the ground from $8 \mathrm{AM}$ to $5 \mathrm{PM}$ on two consecutive days, giving a sampling effort of $18 \mathrm{~h}$ per trap per collection, or a total of $432 \mathrm{~h}$.

The bees collected were sacrificed and then transferred to individual paper bags identified with the time, date, collection method, and georeference. Specimens were mounted in the Bee Studies Laboratory (LEA) and deposited in the laboratory collection (LEACOL) at the Federal University of Maranhão (UFMA) for subsequent species-level identification.

2.4. Data Analysis. Bee community patterns were characterized with the Shannon-Wiener ( $\left.\mathrm{H}^{\prime}\right)$ and Simpson (D) diversity indices. Equitability was characterized with the Pielou index (J'). The calculations for these analyses were performed with vegan [41] in $\mathrm{R}$ version 3.5.0 [42].

The Whittaker abundance distribution model (rankabundance curve) was used to analyze species evenness visually [43].

Occurrence frequency (OF) and dominance (DM) were calculated according to Palma [44], where OF = the number of samples containing species $i$ /the number of samples $\times 100$. If $\mathrm{OF} \geq 50 \%$, the species is considered very frequent (VF); if $25 \%>\mathrm{OF}<50 \%$, it is considered frequent $(\mathrm{F})$; and if $\mathrm{OF} \leq 25 \%$, it is considered infrequent (IF). Dominance was calculated as $\mathrm{DM}=$ abundance of species $i$ /overall abundance $\times 100$, where $\mathrm{DM}>5 \%$ corresponds to a dominant species (D), $2.5 \%>\mathrm{DM} \leq 5 \%$ to an accessory species (A), and $\mathrm{DM} \leq 2.5 \%$ to an occasional species (OC).

According to Buschini [45] and Aguiar and Gaglianone [46], OF and DM can be used together to classify a species into one of three categories: common (very frequent or frequent + dominant), rare (infrequent + occasional), and intermediate (other combinations).

To determine sampling sufficiency, a species accumulation curve was plotted (collector's curve) with EstimateS version 8.2.0 [47]. Nonparametric richness estimators were calculated based on 1000 permutations to determine whether the sampling effort was sufficient to reach the total number of species in the community. The chosen estimators were Chao 1 and jackknife 1 as the former is based on the 


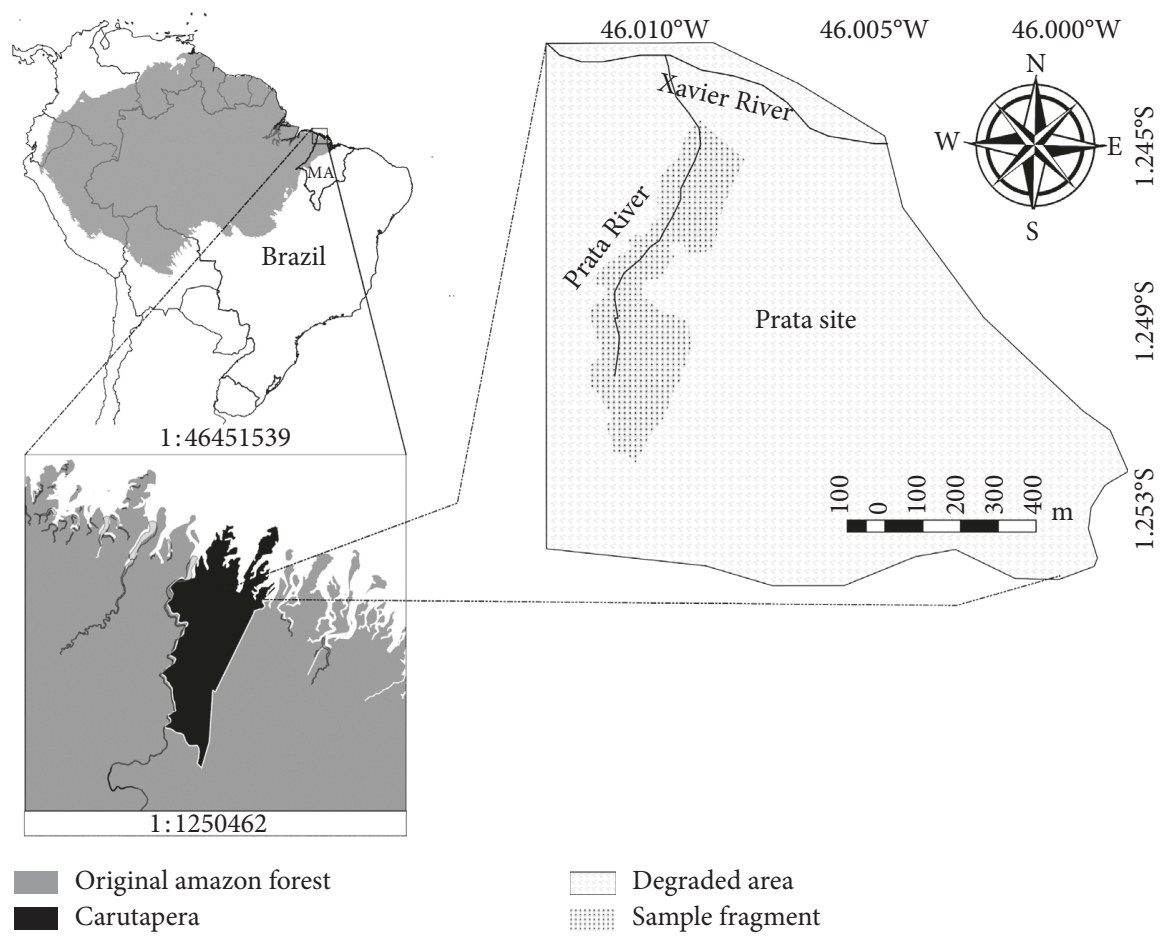

Figure 1: Geographic location of the study area in the municipality of Carutapera, Maranhão, Brazil.

abundance of the sampled species, while the latter considers the number of rare species [43].

Spearman's correlation was used to determine whether there was a correlation between rainy/dry periods and the number of species collected in the samples. The results of this test vary between +1 and -1 . The analysis was performed with ISwR [48] in R version 3.5.0 [42].

Climate data were collected from the National Meteorology Institute (INMET) online database for World Meteorological Organization station no. 82198 (Turiaçu, MA), which is approximately $85 \mathrm{~km}$ from the study area and therefore the closest station.

\section{Results}

A total of 1047 individuals from 70 species in 35 genera, 15 tribes, and 3 subfamilies were collected (Table 1). The subfamilies with the greatest abundance and richness were, in decreasing order, Apinae (1039 individuals, 63 species), Halictinae (6 individuals, 5 species), and Megachilinae (2 individuals, 2 species). In the distribution by tribe, Euglossini stood out, with $34.2 \%$ of the species, and was followed by Meliponini (28.5\%), Augochlorini and Xylocopini (7.14\%), and Centridini (5.71\%). The remaining tribes were represented by only one or two species.

The genera with the greatest number of species were Euglossa (17 species, or 24.2\%), Trigona and Xylocopa (5 species each, or $7.14 \%$ ), and Eulaema (4 species, or $5.71 \%$ ). In terms of abundance, the following genera were noteworthy: Trigona (329 individuals, or 31.4\%), Euglossa (321 individuals, or $30.6 \%$ ), Eulaema (115 individuals, or $10.9 \%$ ), Apis (71 individuals, or 6.78\%), Melipona (65 individuals, or 6.2\%), and Bombus and Tetragona (32 individuals, or 3.05\% each). A list of the species showing their abundance and frequency is given in Table 1.

3.1. Captures with an Insect Net. When the insect net was used, a total of 590 individuals from 15 tribes, 31 genera, and 47 species were collected (Table 1). Of these species, 44 were collected exclusively with this method and accounted for $62.8 \%$ of the community richness.

Subfamilies Halictinae and Megachilinae were also collected exclusively when this method was used and accounted for $10 \%$ of total richness but only $0.7 \%$ of total abundance. In Apinae, all the tribes apart from Euglossini (i.e., Apini, Bombini, Centridini, Emphorini, Eucerini, Exomalopsini, Meliponini, Tapinotaspidini, Tetrapedini, and Xylocopini) were mostly captured with a net.

In the tribe Meliponini, 20 species were identified, all collected exclusively with a net (Table 1). Of these, the most represented were Trigona branneri Cockerell, $1912(n=237)$, Trigona pallens (Fabricius, 1798) $(n=49)$, Melipona fasciculata Smith, $1854(n=40)$, Melipona gr. rufiventris sp. $(n=25)$, Trigona lacteipennis Friese, $1900(n=25)$, Trigona fulviventris Guérin, $1844(n=16)$, and Tetragona clavipes (Fabricius, 1804) $(n=16)$.

3.2. Captures with Scent-Baited Traps. When scent baits were used, a total of 451 specimens of Euglossini corresponding to 24 species in five genera were collected (Table 1): Euglossa (17 species), Eulaema (4 species), Eufriesea (1 species), Exaerete (1 species), and Aglae (1 species). These accounted for $43.1 \%$ of the abundance and $34.2 \%$ of the richness of the bees sampled.

The most represented species was Euglossa cordata (Linnaeus, 1758$)(n=88)$, followed by Eulaema cingulata (Fabricius, 
TABle 1: Bee species recorded in Carutapera (MA).

\begin{tabular}{|c|c|c|c|c|c|c|c|c|}
\hline \multirow{3}{*}{ Subfamily/tribe/species } & \multicolumn{4}{|c|}{$\begin{array}{l}\text { No. of individuals per collection } \\
\text { method }\end{array}$} & \multirow{3}{*}{$\begin{array}{l}\text { Total } \\
n(\%)\end{array}$} & \multicolumn{3}{|c|}{ Classes } \\
\hline & \multirow{2}{*}{$N$} & \multicolumn{3}{|c|}{ Bait traps } & & \multirow{2}{*}{$\mathrm{DM}$} & \multirow{2}{*}{$\mathrm{OF}$} & \multirow{2}{*}{ SC } \\
\hline & & EU & EG & $\mathrm{CM}$ & & & & \\
\hline \multicolumn{9}{|l|}{$\begin{array}{l}\text { Apinae } \\
\text { Apini }\end{array}$} \\
\hline Apis mellifera Linnaeus, 1758 & 71 & & & & $71(6.78)$ & $\mathrm{D}$ & MF & $\mathrm{C}$ \\
\hline \multicolumn{9}{|l|}{ Bombini } \\
\hline Bombus (Fervidobombus) brevivillus Franklin, 1913 & 22 & 3 & & 2 & $27(2.58)$ & A & MF & I \\
\hline Bombus (Fervidobombus) transversalis (Olivier, 1789) & 5 & & & & $5(0.48)$ & $\mathrm{OC}$ & $\mathrm{PF}$ & $\mathrm{R}$ \\
\hline \multicolumn{9}{|l|}{ Centridini } \\
\hline Centris (Hemisiella) trigonoides Lepeletier, 1841 & 2 & & & & $2(0.19)$ & OC & $\mathrm{F}$ & I \\
\hline Centris (Trachina) aff. fuscata Lepeletier, 1841 & 7 & & & & $7(0.67)$ & OC & $\mathrm{F}$ & I \\
\hline Centris (Trachina) longimana Fabricius, 1804 & 1 & & & & $1(0.10)$ & OC & $\mathrm{PF}$ & $\mathrm{R}$ \\
\hline Epicharis sp. & 1 & & & & $1(0.10)$ & OC & $\mathrm{PF}$ & $\mathrm{R}$ \\
\hline \multicolumn{9}{|l|}{ Emphorini } \\
\hline Diadasina sp. & 3 & & & & $3(0.29)$ & OC & $\mathrm{F}$ & I \\
\hline Melitoma segmentaria (Fabricius, 1804) & 1 & & & & $1(0.10)$ & OC & $\mathrm{PF}$ & $\mathrm{R}$ \\
\hline \multicolumn{9}{|l|}{ Eucerini } \\
\hline Florilegus (Florilegus) sp. & 1 & & & & $1(0.10)$ & $\mathrm{OC}$ & $\mathrm{PF}$ & $\mathrm{R}$ \\
\hline \multicolumn{9}{|l|}{ Euglossini } \\
\hline Aglae caerulea Lepeletier and Serville, 1825 & & & & 1 & $1(0.10)$ & OC & $\mathrm{PF}$ & $\mathrm{R}$ \\
\hline Eufriesea surinamensis (Linnaeus, 1758) & & 3 & & & $3(0.29)$ & OC & $\mathrm{PF}$ & $\mathrm{R}$ \\
\hline Euglossa (Euglossa) amazonica Dressler, 1982 & & 11 & 5 & 1 & $17(1.62)$ & OC & MF & I \\
\hline Euglossa (Euglossa) cordata (Linnaeus, 1758) & 1 & 56 & 10 & 21 & $88(8.40)$ & $\mathrm{D}$ & MF & $\mathrm{C}$ \\
\hline Euglossa (Euglossa) despecta Moure, 1968 & & 14 & 3 & & $17(1.62)$ & $\mathrm{OC}$ & MF & $\mathrm{I}$ \\
\hline Euglossa (Euglossa) hemichlora Cockerell, 1917 & & 2 & 1 & & $3(0.29)$ & OC & $\mathrm{F}$ & I \\
\hline Euglossa (Euglossa) liopoda Dressler, 1982 & & 1 & & & $1(0.10)$ & OC & $\mathrm{PF}$ & $\mathrm{R}$ \\
\hline Euglossa (Euglossa) modestior Dressler, 1982 & & 30 & 4 & 6 & $40(3.82)$ & A & MF & I \\
\hline Euglossa (Euglossa) platymera Dressler, 1982 & & 1 & & & $1(0.10)$ & OC & $\mathrm{PF}$ & $\mathrm{R}$ \\
\hline Euglossa (Euglossa) securigera Dressler, 1982 & & 8 & 2 & 1 & $11(1.05)$ & OC & MF & $\mathrm{I}$ \\
\hline Euglossa (Euglossa) townsendi Cockerell, 1904 & & 1 & & & $1(0.10)$ & OC & $\mathrm{PF}$ & $\mathrm{R}$ \\
\hline Euglossa (Euglossa) truncata Rebêlo and Moure, 1996 & & 3 & & & $3(0.29)$ & OC & $\mathrm{F}$ & I \\
\hline Euglossa (Euglossella) viridis (Perty, 1833) & & 1 & & & $1(0.10)$ & OC & $\mathrm{PF}$ & $\mathrm{R}$ \\
\hline Euglossa (Glossura) chalybeata Friese, 1925 & & 1 & & & $1(0.10)$ & OC & $\mathrm{PF}$ & $\mathrm{R}$ \\
\hline Euglossa (Glossura) ignita Smith, 1874 & & 45 & 1 & 8 & $54(5.16)$ & $\mathrm{D}$ & MF & $\mathrm{C}$ \\
\hline Euglossa (Glossura) piliventris Guérin, 1844 & & 2 & 1 & 25 & $28(2.67)$ & A & MF & I \\
\hline Euglossa (Glossurella) augaspis Dressler, 1982 & & & & 1 & $1(0.10)$ & OC & $\mathrm{PF}$ & $\mathrm{R}$ \\
\hline Euglossa (Glossurella) bursigera Moure, 1970 & & 1 & & & $1(0.10)$ & OC & $\mathrm{PF}$ & $\mathrm{R}$ \\
\hline Euglossa (Glossuropoda) intersecta Latreille, 1817 & & 53 & & & $53(5.06)$ & $\mathrm{D}$ & MF & $\mathrm{C}$ \\
\hline Eulaema (Apeulaema) cingulata (Fabricius, 1804) & & & 71 & 1 & $72(6.88)$ & $\mathrm{D}$ & MF & $\mathrm{C}$ \\
\hline Eulaema (Apeulaema) nigrita Lepeletier, 1841 & & 34 & & & $34(3.25)$ & A & MF & I \\
\hline Eulaema (Eulaema) bombiformis (Packard, 1869) & & & & 4 & $4(0.38)$ & OC & MF & $\mathrm{I}$ \\
\hline Eulaema (Eulaema) meriana (Olivier, 1789) & & 4 & 1 & & $5(0.48)$ & OC & $\mathrm{F}$ & I \\
\hline Exaerete smaragdina (Guérin, 1844) & & 8 & 4 & & $12(1.15)$ & $\mathrm{OC}$ & MF & $\mathrm{I}$ \\
\hline \multicolumn{9}{|l|}{ Exomalopsini } \\
\hline Exomalopsis (Exomalopsis) analis Spinola, 1853 & 2 & & & & $2(0.19)$ & OC & $\mathrm{PF}$ & $\mathrm{R}$ \\
\hline Meliponini & & & & & & & & \\
\hline Aparatrigona impunctata (Ducke, 1916) & 3 & & & & $3(0.29)$ & OC & $\mathrm{F}$ & I \\
\hline Frieseomelitta flavicornis (Fabricius, 1798) & 1 & & & & $1(0.10)$ & OC & $\mathrm{PF}$ & $\mathrm{R}$ \\
\hline Lestrimelitta limao (Smith, 1863) & 3 & & & & $3(0.29)$ & OC & $\mathrm{PF}$ & $\mathrm{R}$ \\
\hline Melipona (Melikerria) fasciculata Smith, 1854 & 40 & & & & $40(3.82)$ & A & $\mathrm{F}$ & I \\
\hline Melipona (Michmelia) gr. rufiventris sp. & 25 & & & & $25(2.39)$ & OC & $\mathrm{F}$ & I \\
\hline Nannotrigona punctata (Smith, 1854) & 1 & & & & $1(0.10)$ & OC & $\mathrm{PF}$ & $\mathrm{R}$ \\
\hline Oxytrigona ignis Camargo, 1984 & 2 & & & & $2(0.19)$ & OC & $\mathrm{PF}$ & $\mathrm{R}$ \\
\hline Partamona (Partamona) ailyae Camargo, 1980 & 1 & & & & $1(0.10)$ & OC & $\mathrm{PF}$ & $\mathrm{R}$ \\
\hline Partamona chapadicola Pedro and Camargo, 2003 & 4 & & & & $4(0.38)$ & OC & $\mathrm{PF}$ & $\mathrm{R}$ \\
\hline Plebeia sp. & 2 & & & & $2(0.19)$ & OC & $\mathrm{PF}$ & $\mathrm{R}$ \\
\hline Scaura latitarsis (Friese, 1900) & 1 & & & & $1(0.10)$ & OC & $\mathrm{PF}$ & $\mathrm{R}$ \\
\hline
\end{tabular}


TABLE 1: Continued.

\begin{tabular}{|c|c|c|c|c|c|c|c|c|}
\hline \multirow{3}{*}{ Subfamily/tribe/species } & \multicolumn{4}{|c|}{$\begin{array}{l}\text { No. of individuals per collection } \\
\text { method }\end{array}$} & \multirow{3}{*}{$\begin{array}{l}\text { Total } \\
n(\%)\end{array}$} & \multicolumn{3}{|c|}{ Classes } \\
\hline & \multirow{2}{*}{$N$} & \multicolumn{3}{|c|}{ Bait traps } & & \multirow{2}{*}{$\mathrm{DM}$} & \multirow{2}{*}{$\mathrm{OF}$} & \multirow{2}{*}{ SC } \\
\hline & & $\mathrm{EU}$ & EG & $\mathrm{CM}$ & & & & \\
\hline Tetragona clavipes (Fabricius, 1804) & 16 & & & & $16(1.53)$ & OC & $\mathrm{F}$ & $\mathrm{I}$ \\
\hline Tetragona dorsalis (Smith, 1854) & 14 & & & & $14(1.34)$ & OC & $\mathrm{PF}$ & $\mathrm{R}$ \\
\hline Tetragona sp. & 2 & & & & $2(0.19)$ & OC & $\mathrm{PF}$ & $\mathrm{R}$ \\
\hline Trigona branneri Cockerell, 1912 & 237 & & & & $237(22.64)$ & $\mathrm{D}$ & MF & $\mathrm{C}$ \\
\hline Trigona fulviventris Guérin, 1844 & 16 & & & & $16(1.53)$ & $\mathrm{OC}$ & $\mathrm{F}$ & $\mathrm{I}$ \\
\hline Trigona lacteipennis Friese, 1900 & 25 & & & & $25(2.39)$ & OC & $\mathrm{PF}$ & $\mathrm{R}$ \\
\hline Trigona pallens (Fabricius, 1798) & 49 & & & & $49(4.68)$ & A & $\mathrm{PF}$ & $\mathrm{I}$ \\
\hline Trigona spinipes (Fabricius, 1793) & 2 & & & & $2(0.19)$ & $\mathrm{OC}$ & $\mathrm{F}$ & $\mathrm{I}$ \\
\hline $\begin{array}{l}\text { Trigonisca meridionalis Albuquerque and Camargo, } \\
2007\end{array}$ & 1 & & & & $1(0.10)$ & $\mathrm{OC}$ & $\mathrm{PF}$ & $\mathrm{R}$ \\
\hline Nomadini & & & & & & & & \\
\hline Thalestria spinosa (Fabricius, 1804) & 2 & & & & $2(0.19)$ & OC & $\mathrm{PF}$ & $\mathrm{R}$ \\
\hline Tapinotaspidini & & & & & & & & \\
\hline Paratetrapedia leucostoma (Cockerell, 1923) & 1 & & & & $1(0.10)$ & $\mathrm{OC}$ & $\mathrm{PF}$ & $\mathrm{R}$ \\
\hline Tetrapedini & & & & & & & & \\
\hline Tetrapedia diversipes Klug, 1810 & 2 & & & & $2(0.19)$ & OC & $\mathrm{PF}$ & $\mathrm{R}$ \\
\hline Xylocopini & 1 & & & & $1(0.10)$ & OC & $\mathrm{PF}$ & $\mathrm{R}$ \\
\hline Xylocopa (Neoxylocopa) aurulenta (Fabricius, 1804) & & & & & & & & \\
\hline Xylocopa (Neoxylocopa) frontalis (Olivier, 1789) & 7 & & & & $7(0.67)$ & $\mathrm{OC}$ & $\mathrm{F}$ & $\mathrm{I}$ \\
\hline $\begin{array}{l}\text { Xylocopa (Neoxylocopa) suspecta Moure and } \\
\text { Camargo, } 1988\end{array}$ & 3 & & & & $3(0.29)$ & OC & $\mathrm{PF}$ & $\mathrm{R}$ \\
\hline Xylocopa (Schonnherria) macrops Lepeletier, 1841 & 1 & & & & $1(0.10)$ & OC & $\mathrm{PF}$ & $\mathrm{R}$ \\
\hline Xylocopa (Schonnherria) muscaria (Fabricius, 1775) & 3 & 1 & & & $4(0.38)$ & $\mathrm{OC}$ & $\mathrm{PF}$ & $\mathrm{R}$ \\
\hline $\begin{array}{l}\text { Halictinae } \\
\text { Augochlorini }\end{array}$ & & & & & & & & \\
\hline Auglochora sp. & 1 & & & & $1(0.10)$ & OC & $\mathrm{PF}$ & $\mathrm{R}$ \\
\hline Augochlorella sp. & 2 & & & & $2(0.19)$ & $\mathrm{OC}$ & $\mathrm{F}$ & $\mathrm{R}$ \\
\hline Augochloropsis sp. 1 & 1 & & & & $1(0.10)$ & OC & $\mathrm{PF}$ & $\mathrm{R}$ \\
\hline Augochloropsis sp. 2 & 1 & & & & $1(0.10)$ & $\mathrm{OC}$ & $\mathrm{PF}$ & $\mathrm{R}$ \\
\hline Pseudaugochlora pandora Smith, 1853 & 1 & & & & $1(0.10)$ & $\mathrm{OC}$ & $\mathrm{PF}$ & $\mathrm{R}$ \\
\hline $\begin{array}{l}\text { Megachilinae } \\
\text { Anthidini }\end{array}$ & & & & & & & & \\
\hline Hypanthidium maranhense Urban, 1998 & 1 & & & & $1(0.10)$ & OC & $\mathrm{PF}$ & $\mathrm{R}$ \\
\hline Megachilini & & & & & & & & \\
\hline Megachile sp. & 1 & & & & $1(0.10)$ & $\mathrm{OC}$ & $\mathrm{PF}$ & $\mathrm{R}$ \\
\hline Total & 590 & 283 & 103 & 71 & 1047 & & & \\
\hline
\end{tabular}

1804) ( $n=72)$, Euglossa ignita Smith, $1874(n=54)$, Euglossa intersecta Latreille, $1817(n=53)$, Euglossa modestior Dressler, $1982(n=40)$, Eulaema nigrita Lepeletier, $1841(n=34)$, and Euglossa piliventris Guérin, $1844(n=28)$.

The most attractive bait was eucalyptol, and traps with this scent accounted for 283 individuals from 22 species. The species most attracted to this scent was E. cordata and $E$. intersecta (males), E. nigrita, Eufriesea surinamensis (Linnaeus, 1758), Euglossa truncata Rebêlo and Moure, 1996, Euglossa liopoda Dressler, 1982, Euglossa chalybeata Friese, 1925 , and other five species were attracted exclusively by this substance and accounted for $14.2 \%$ of the sampled richness in the study location.

Eugenol was the second most attractive substance and accounted for 103 individuals from 11 species $(15.7 \%$ of the richness). It was the most attractive scent for E. cingulata and no exclusive species in the sample. Methyl cinnamate attracted 71 individuals from 11 species and was the only scent that attracted Aglae caerulea Lepeletier and Serville, 1825, Euglossa augaspis Dressler, 1982, and Eulaema bombiformis (Packard, 1869) (4.3\% of the richness).

Euglossa amazonica Dressler, 1982, E. cordata, E. modestior, Euglossa securigera Dressler, 1982, E. ignita, and E. piliventris were attracted by all three scents.

3.3. Community Fluctuation. The month with the greatest bee richness was August 2014, at the end of the rainy season (30 species) (Figure 2). Although December 2013 and December 2014 had the greatest bee abundance (187 and 176 

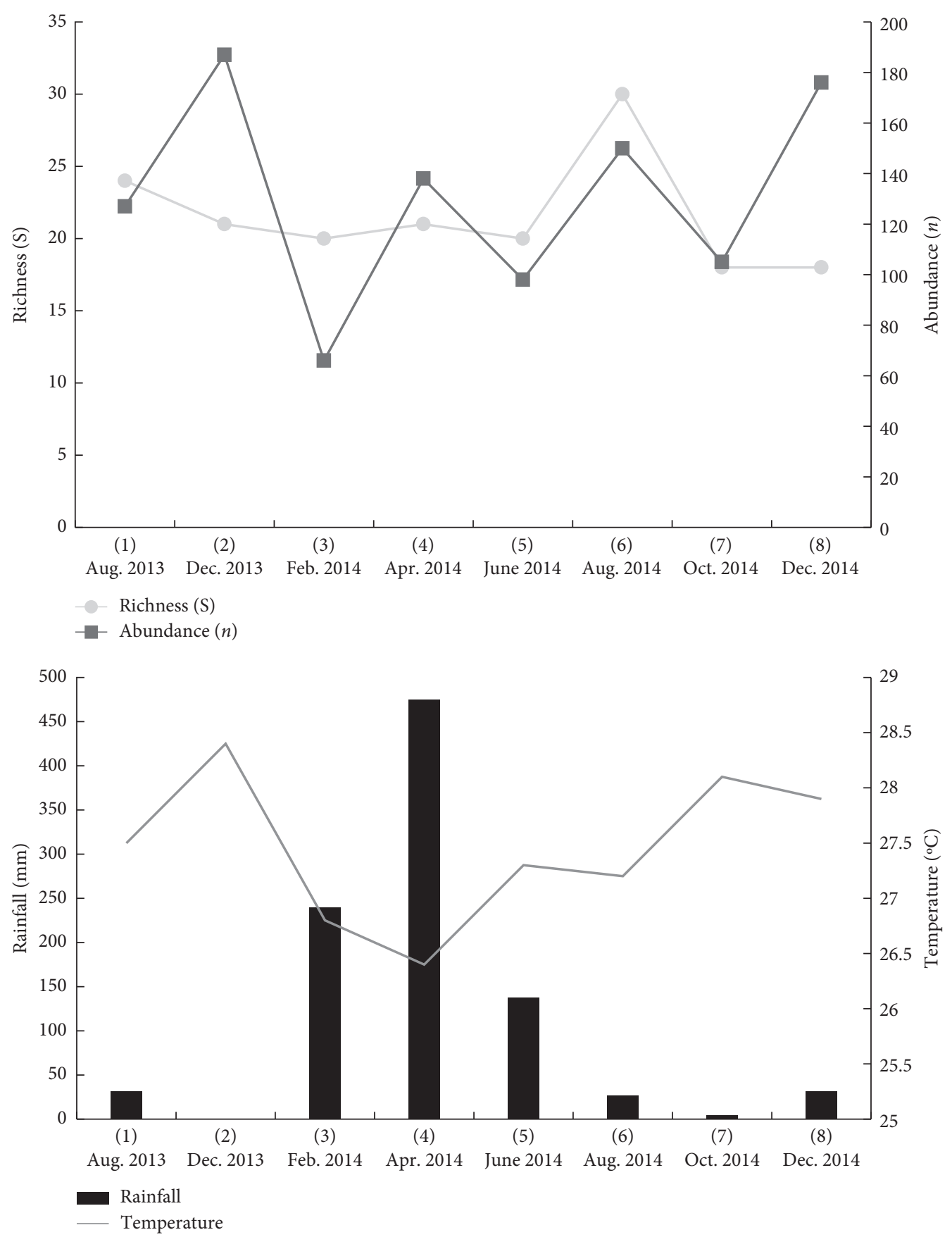

FIgURE 2: Distribution of bee sample richness and abundance and climate data between August 2013 and December 2014 in Carutapera, MA, Brazil.

individuals, respectively), no significant correlation between climate patterns and diversity patterns was observed $(r=-0.109 ; p=0.797)$.

Based on the annual distribution, $22.9 \%$ of the species was considered very frequent, $20 \%$ frequent, and $57.1 \%$ infrequent, of which 26 were solitary species (Table 1). E. cordata was the only species present in every collection month. Of all the specimens, $8.57 \%$ were dominant, $8.57 \%$ accessory, and $82.8 \%$ occasional. When dominance and frequency were combined, six species were classified as common, 24 as intermediate, and 40 as rare (Table 1).
3.4. Sampling Sufficiency. The bee community in this forest environment proved relatively uniform $(P=0.72)$, an indication that most species were represented by only a few individuals (Figure 3).

The species accumulation curve did not level off (Figure 4), showing that the expected number of species was greater than the number actually collected. Because of this, nonparametric total richness estimators were used.

The results with these were Jackknife $1=102.6$ and Chao $1=145.5$. Overall, bee diversity in Carutapera was relatively high $\left(H^{\prime}=3.08\right)$, and species dominance was low $(D=0.08)$. 


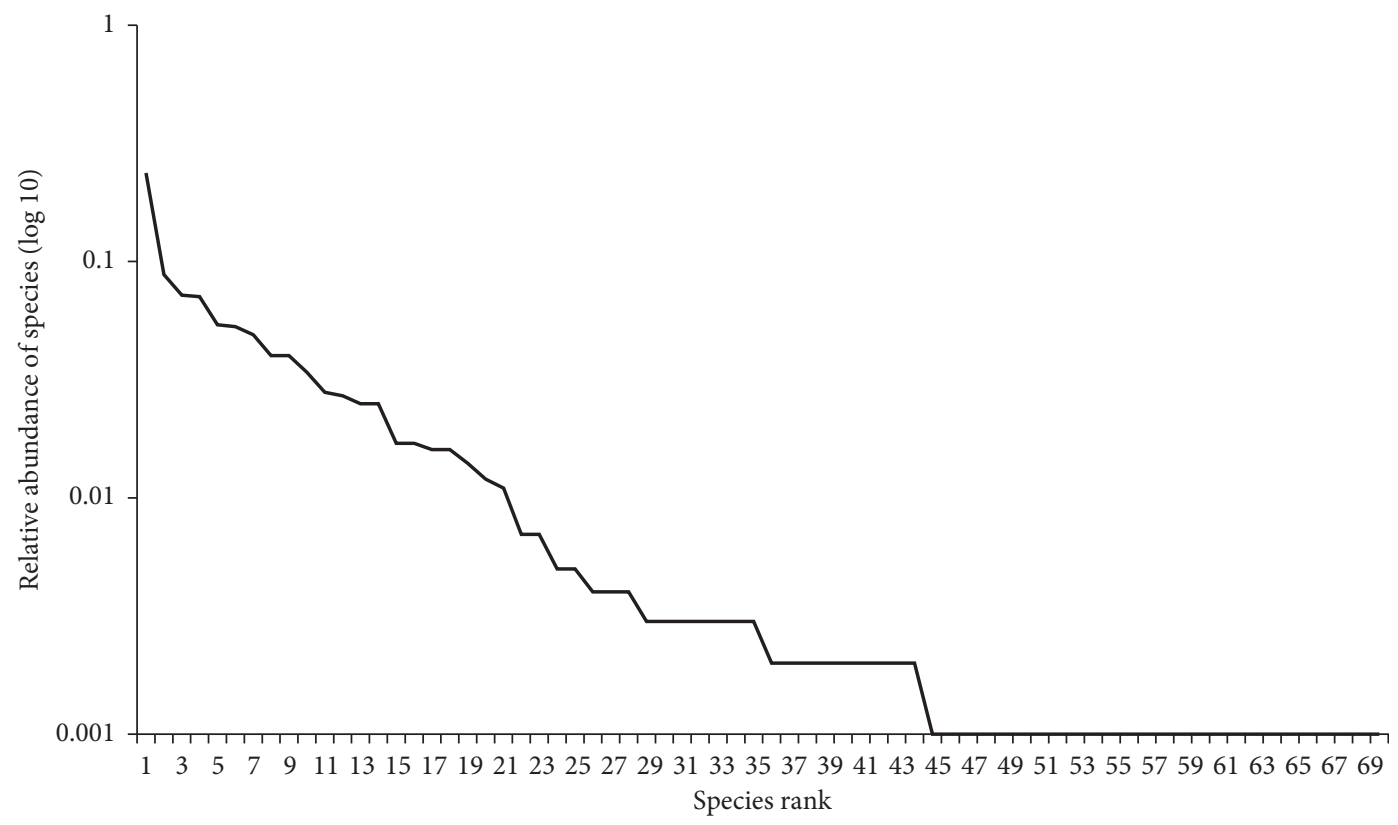

FIgURE 3: Rank-abundance curve for bee species between August 2013 and December 2014 in Carutapera, MA.

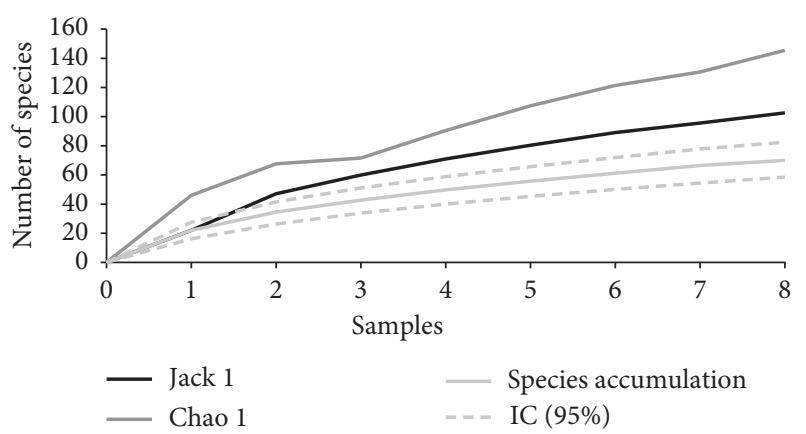

FIGURE 4: Nonparametric richness estimators (Chao 1 and Jackknife 1) and species accumulation curve (collector's curve) for bees in Carutapera, MA, between August 2013 and December 2014.

\section{Discussion}

The bee diversity observed in Carutapera was greater than that reported in other studies and ecosystems using more than one collection technique, such as those by Pereira [49] in Cerrado, Kamke et al. [18] in restinga, Batalha-filho et al. [50] in caatinga (an area with xerophilous spiny trees and shrubs) and Krug and Alves-dos-Santos [32] and Gruchowski et al. [51] in the Atlantic forest. Comparisons of fauna in different locations are important for an understanding of communities and ecosystems but are made difficult by the existence of many variables, such as differences between collectors and sampling effort [52], capture modes [32, 53], and climate/geographic variations [54-56].

Venturieri and Contrera [57] discuss the great dearth of standardized surveys of Apoidea in the Amazon biome, the last having been carried out over 100 years ago by Ducke [58]. Since then, few studies of Apoidea in this biome have been published, and the majority of these has been surveys of the tribe Euglossini [49, 59-62]. In eastern Amazonia, where the state of Maranhão is, four surveys have been carried out $[6,14,16,22]$, although only one of them, which was carried out in the Baixada Maranhense environmental protection area [6], used more than one sampling method.

In the present study, with only half the sampling period and the same collection methods as Albuquerque et al. [6], we recorded similar abundances yet twice the richness. However, the richness was lower than that reported by Poveda-Coronel et al. [63] in a study also carried out in a degraded region of the Amazon; a possible explanation for this is that Poveda-Coronel et al. [63] used two types of trap (trap nest and malaise) in addition to the type of trap used here.

For the remaining studies in which only one sampling method was used, whether an insect net $[7,17,19,22]$ or scentbaited traps [8-11, 14, 16, 64, 65], comparisons in terms of species richness will be presented for the relevant method.

If we consider the data presented here for collections with an insect net, the richness was higher than that reported in any of the studies in the state of Maranhão identified in the literature. This method therefore proved to be the most efficient, as already mentioned in other studies $[18,32]$ since it alone accounted for $62.8 \%$ of the species sampled in the study area.

Subfamily Apinae was notable in the present study, reflecting the known tendency for the species richness of this subfamily to increase at lower latitudes $[17,19,66]$, while Andreninae and Colletinae are known to be poorly represented in the neotropical realm [67], explaining the possible absence of these two subfamilies in the community studied.

The tribe Meliponini was noteworthy primarily for its abundance, a consequence of the social nature of the species in this tribe, which have many nests near each other. According to Roubik [68], the evolutionary success of this group is associated with eusocial behavior, perennial colonies, and Catholic foraging habits. Worker bees in these species have a highly developed ability to communicate 
information about the location of food sources to other workers [69] and have large colonies [51, 70], so that many individuals from a single colony may be observed on flowers [71].

The stingless bee T. branneri was dominant throughout the sampling period and therefore was very frequent; this finding disagrees with the results of most other studies in the state of Maranhão, in which this species was absent $[5,12,26,72]$. Presumably, this species is better adapted to forests even if they are degraded, as observed by Oliveira et al. [73] for other species of the same genus in continuous and fragmented areas in central Amazonia.

The exotic species Apis mellifera Linnaeus, 1758, was also very abundant throughout the sampling period, a finding similar to that reported by Poveda-Coronel et al. [63], who discusses this species resistance not only to the effects of habitat fragmentation but also to climate change, which is increasingly noticeable in tropical regions of the planet.

In the case of solitary bees, there was a general pattern of low abundance, which is probably related to their seasonal lifecycle and the fact that nestbuilding generally occurs in the summer [74, 75].

Turning to scent baits, the tribe Euglossini was most notable and accounted for a significant percentage of the community (34.2\%); species richness for this tribe was higher than that reported in other studies in the Amazonian region [14, 59, 72] and in a transition area between Cerrado and the Amazon forest [76]. However, the species richness observed for the forest fragment in Carutapera was similar to that reported in other studies in areas with the same type of plant formation that are also under threat from human activity, such as the study by Brito et al. [61] in oil palm plantations in the state of Pará. This result is probably related to the adverse conditions in the study area, which is subjected to constant degradative pressures due to burning, clearing, and logging in neighboring areas [77], a situation reflected in our data by the presence of species such as E. cordata and E. nigrita. These are generally associated with open areas and areas subjected to stresses caused by human activity [78] and were classified as very frequent in the present study.

It is also possible that these findings simply reflect the sampling method chosen as the only most common baits in orchid bee studies [39, 49, 79] that were used here. For Bezerra and Martins [80], the use of different types of baits is an efficient way of sampling the tribe Euglossini as some species have preferences for particular baits [37, 81].

In the present study, eucalyptol was the most attractive scent both in terms of number of individuals and number of species. This is a pattern that has been observed in many studies [11, 14, 49, 82]. Sofia and Suzuki [79] found that the greater attractiveness of eucalyptol baits was due to the greater volatility of this essential oil compared with other scents. This greater attractiveness resulted in Eulaema nigrita and Euglossa intersecta mainly visiting baits containing eucalyptol, a pattern also observed in other studies [14, 83].

Eugenol was the second most attractive bait, especially for $E$. cingulata because of its low volatility [84, 85]. Although methyl cinnamate was the least attractive essence, it was the only one that attracted $A$. caerulea, which was considered endemic only to the northern Amazon region prior to the study by AnjosSilva et al. [81]. Recently, Martins et al. [39] also collected specimens of this species using methyl cinnamate and reported its presence in Maranhão for the first time.

In our study, a pattern of a few species with many individuals and many intermediate and rare species was observed. In spite of this, the equitability index was high. Although the data collected were insufficient to determine whether there was a seasonal distribution of individuals, as collections were only performed in eight months, we observed two abundance peaks (December 2013 and December 2014), corresponding to the dry period, and abundance was lowest in February 2014.

The abundance peaks corresponded to the periods when the greatest number of species from Meliponini were collected. According to Pedro and Camargo [86], the activity of stingless bees is related more to the availability of resources than to climate variations. The richness peak in August 2014 is probably related to the blooming period at the beginning of spring, when various botanical species produce abundant floral resources [87].

Unsampled species, indicated by the richness estimators (Chao $1=51.8 \%$ and Jackknife $1=31.7 \%$ ), highlight the importance of carrying out further long-term standardized studies in transition areas on the edge of the Amazon region, especially because this is an environment whose diversity has been underestimated in terms of its complexity [88].

However, our data show a high level of diversity, demonstrating, as other authors have [18, 32, 89, 90], that complementary methods can help to assess the bee community structure in a particular environment.

We have added three new records for the state of Maranhão: Bombus transversalis (Olivier, 1789), Xylocopa suspecta Moure and Camargo, 1988, and Xylocopa macrops Lepeletier, 1841. In addition, 11 new species were recorded for the first time in the Amazonian region of the state: $A$. caerulea, E. amazonica, Euglossa despecta Moure, 1968, E. bombiformis, Aparatrigona impunctata (Ducke, 1916), Frieseomelitta flavicornis (Fabricius, 1798), Lestrimelitta limao (Smith, 1863), Partamona chapadicola Pedro and Camargo, 2003, Trigonisca meridionalis Albuquerque and Camargo, 2007, Paratetrapedia leucostoma (Cockerell, 1923), and Tetrapedia diversipes Klug, 1810.

\section{Conclusions}

Bee diversity in the study region was the highest yet recorded in the state of Maranhão. This can be attributed to the particularities of this transition region and the combined use of two collection methods known to be the most effective for bees. Although we did not find any statistically significant correlation with climate patterns, we observed abundance peaks in months corresponding to the dry period. The results presented here help to gain an understanding of bee composition and distribution in northernmost Maranhão. Eleven new occurrences were recorded for the Amazonian region of the state and three for the whole state. 


\section{Data Availability}

All data used to support the findings of this study are available from the corresponding author upon request.

\section{Conflicts of Interest}

The authors declare that they have no conflicts of interest.

\section{Acknowledgments}

The authors would like to thank the State of Maranhão Research Foundation (FAPEMA) for providing financial support for the CBIOMA Project (ref. no. 02930/12) and an undergraduate research project scholarship for LACF; the Federal University of Maranhão (UFMA) and the Bee Studies Laboratory (LEA) for providing logistical and technical support; and Dr. Fernando Amaral da Silveira (UFMG), Dr. Silvia Regina de Menezes Pedro (USP), and Dr. José Manuel Macário Rebêlo (UFMA) for providing specialist help with species identification.

\section{References}

[1] I. Silberbauer-Gottsberger and G. Gottsberger, "A polinização de plantas do cerrado," Revista Brasileira de Biologia, vol. 48, no. 4, pp. 651-663, 1988.

[2] C. D. Michener, The Bees of the World, The John Hopkins Press, Washington, DC, USA, 2000

[3] F. A. Silveira, G. A. R. Melo, and E. A. B. Almeida, "Abelhas brasileiras-Sistemática de Identificação," Belo Horizonte, p. 253, 2002.

[4] J. S. Moure, D. Urban, and G. A. R. Melo, Catalogue of Bees (Hymenoptera, Apoidea) in the Neotropical Region, Sociedade Brasileira de Entomologia Curitiba, Curitiba, Brazil, 2007.

[5] M. M. C. Rêgo and P. M. C. Albuquerque, Biodiversidade de Abelhas em zonas de Transição no Maranhão. Embrapa SemiÁrido, vol. 249, Embrapa Semiárido, Petrolina, PE, Brazil, 2012http://www.cpatsa.embrapa.br:8080/public_eletronica/ downloads/SDC249.pdf.

[6] P. M. C. Albuquerque, R. G. Ferreira, M. M. C. Rêgo, C. S. Santos, and C. M. S. Brito, "Levantamento da fauna de abelhas silvestres (Hymenoptera, Apoidea) na região da "Baixada Maranhense": Vitória do Mearim, MA, Brasil," Acta Amazonica, vol. 31, no. 3, pp. 45-54, 2001.

[7] P. M. C. Albuquerque and J. A. C. Mendonça, "Anthophoridae (Hymenoptera; Apoidea) e flora associada em uma formação de Cerrado no município de Barreirinhas, MA, Brasil," Acta Amazonica, vol. 26, no. 1-2, pp. 55-68, 1996.

[8] C. C. D. Carvalho, M. M. C. Rêgo, and F. N. Mendes, "Dinâmica de populações de Euglossina (Hymenoptera, Apidae) em mata ciliar, Urbano Santos, Maranhão, Brasil," Iheringia. Série Zoologia, vol. 96, no. 2, pp. 249-256, 2006.

[9] D. C. Martins, P. M. C. Albuquerque, F. S. Silva, and J. M. M. Rebêlo, "Orchid bees (Apidae: Euglossini) in cerrado remnants in northeast Brazil," Journal of Natural History, vol. 52, no. 11-12, pp. 627-644, 2018.

[10] F. N. Mendes, M. M. C. Rêgo, and C. C. D. Carvalho, "Abelhas Euglossina (Hymenoptera, Apidae) coletadas em uma monocultura de eucalipto circundada por Cerrado em Urbano Santos, Maranhão, Brasil," Iheringia. Série Zoologia, vol. 98, no. 3, pp. 285-290, 2008.
[11] J. M. M. Rebêlo and A. D. J. M. Cabral, "Abelhas Euglossinae de barreirinhas, zona do Litoral Da Baixada Oriental maranhense," Acta Amazonica, vol. 27, no. 2, pp. 145-152, 1997.

[12] M. M. C. Rêgo, "The bees of "Gerais de balsas"," in Cerrado Norte do Brasil, L. Barreto, Ed., vol. 10, pp. 157-176, USEB, Brazil, 2007.

[13] B. D. V. Serra, M. S. Drummond, L. D. M. Lacerda, and I. P. Akatsu, "Abundância, distribuição espacial de ninhos de abelhas Meliponina (Hymenoptera, Apidae, Apini) e espécies vegetais utilizadas para nidificação em áreas de cerrado do Maranhão," Iheringia. Série Zoologia, vol. 99, no. 1, pp. 12-17, 2009.

[14] C. M. S. D. Brito and M. M. C. Rêgo, "Community of male Euglossini bees (Hymenoptera: Apidae) in a secondary forest, Alcântara, MA, Brazil," Brazilian Journal of Biology, vol. 61, no. 4, pp. 631-638, 2001.

[15] S. D. J. M. Gonçalves, M. Rêgo, and A. D. Araújo, "Abelhas sociais (Hymenoptera: Apidae) E Seus recursos florais em Uma região de mata Secundária, Alcântara, Ma, brasil," Acta Amazonica, vol. 26, no. 1-2, pp. 55-68, 1996.

[16] F. S. Silva and J. M. M. Rebêlo, "Euglossine bees (Hymenoptera: Apidae) of buriticupu, Amazonia of Maranhão, Brazil1," Acta Amazonica, vol. 29, no. 4, pp. 587-585, 1999.

[17] P. M. C. D. Albuquerque, J. M. F. D. Camargo, and J. Â. C. Mendonça, "Bee community of a beach dune ecosystem on Maranhão Island, Brazil," Brazilian Archives of Biology and Technology, vol. 50, no. 6, pp. 1005-1018, 2007.

[18] R. Kamke, A. Zillikens, and J. Steiner, "Species richness and seasonality of bees (Hymenoptera, Apoidea) in a restinga area in Santa Catarina, southern Brazil," Studies on Neotropical Fauna and Environment, vol. 46, no. 1, pp. 35-48, 2011.

[19] F. S. Oliveira, M. W. A. Mendonça, M. C. S. Vidigal, M. M. C. Rêgo, and P. M. C. Albuquerque, "Comunidade de abelhas (Hymenoptera, Apoidea) em ecossistema de dunas na Praia de Panaquatira, São José de Ribamar, Maranhão, Brasil," Revista Brasileira de Entomologia, vol. 54, no. 1, pp. 82-90, 2010.

[20] O. Silva, M. M. C. Rego, P. M. C. Albuquerque, and M. C. Ramos, "Abelhas Euglossina (Hymenoptera: Apidae) em área de restinga do nordeste do Maranhão," Neotropical Entomology, vol. 38, no. 2, pp. 186-196, 2009.

[21] M. B. Rebêlo and T. G. Oliveira, Amazônia maranhense: Diversidade e conservação, Museu Paraense Emílio Goeldi, Belém, Brazil, 2011.

[22] INPE. Instituto Nacional de Pesquisas Espaciais, Projeto PRODES Monitoramento da Floresta Amazônica Brasileira por Satélite, INPE. Instituto Nacional de Pesquisas Espaciais, São José dos Campos, Brazil, 1988, http://www.obt.inpe.br/ prodes/index.php.

[23] B. S. Soares-Filho, D. C. Nepstad, L. M. Curran et al., "Modelling conservation in the Amazon basin," Nature, vol. 440, no. 7083, pp. 520-523, 2006.

[24] E. P. Araújo, J. R. Lopes, and R. C. Filho, "Aspectos socioeconômicos e de evolução do desmatamento na Amazônia maranhense," in Oliveira TG. 2011. Amazônia maranhense: Diversidade e conservação, M. B. Martins, Ed., pp. 35-44, MPEG, Belém, PA, Brazil, 2011.

[25] F. H. Muniz, "Efeito do manejo florestal sobre a composição florística e fitossociologia da floresta na Amazônia maranhense," in Oliveira TG. 2011. Amazônia maranhense: Diversidade e conservação, M. B. Martins, Ed., pp. 35-44, 2011.

[26] J. M. M. Rebêlo, M. M. C. Rêgo, and P. M. C. Albuquerque, "Distribuição, uso e conservação de abelhas - Hymenoptera, Apidae-na Amazônia maranhense," in Oliveira TG. 2011. 
Amazônia maranhense: Diversidade e conservação, M. B. Martins, Ed., pp. 35-44, MPEG, Belém, PA, Brazil, 2011.

[27] B. M. Freitas, V. L. Imperatriz-Fonseca, L. M. Medina et al., "Diversity, threats and conservation of native bees in the neotropics," Apidologie, vol. 40, no. 3, pp. 332-346, 2009.

[28] S. G. Potts, J. C. Biesmeijer, C. Kremen, P. Neumann, O. Schweiger, and W. E. Kunin, "Global pollinator declines: trends, impacts and drivers," Trends in Ecology \& Evolution, vol. 25, no. 6, pp. 345-353, 2010.

[29] E. F. Morato, S. T. Amarante, and O. T. Silveira, "Avaliação ecológica rápida da fauna de vespas (Hymenoptera: Aculeata) do Parque Nacional da Serra do Divisor, Acre, Brasil," Acta Amazonica, vol. 38, no. 4, pp. 789-797, 2008.

[30] A. Nemésio, "The orchid-bee fauna (Hymenoptera: Apidae) of a forest remnant in southern Bahia, Brazil, with new geographic records and an identification key to the known species of the area," Zootaxa, vol. 2821, no. 1, pp. 47-54, 2011.

[31] T. F. Brito, A. C. S. Santos, M. M. Maués, O. T. Silveira, and M. L. Oliveira, "Historical records of orchid bees (Apidae: Euglossini) in Belém Endemism Center: species list of 92 years sampling," Brazilian Journal of Biology, vol. 79, no. 2, pp. 263-272, 2018.

[32] C. Krug and I. Alves-dos-Santos, "O uso de diferentes métodos para amostragem da fauna de abelhas (Hymenoptera: Apoidea), um estudo em floresta ombrófila mista em Santa Catarina," Neotropical Entomology, vol. 37, no. 3, pp. 265-278, 2008.

[33] A. L. Velloso, E. Sampaio, and F. Pareyn, "Ecorregiões propostas para o bioma Caatinga. Recife: Associação Plantas do Nordeste, Instituto de Conservação Ambiental," The Nature Conservancy Do Brasil, vol. 74, no. 7, 2002.

[34] W. Koppen, Climatologia. México, Fundo de Cultura Econômica, Fondo de Cultura Econômica, Mexico City, Mexico, 1931.

[35] INMET. Instituto Nacional de Meteorologia, 2010, Brazil http://www.inmet.gov.br/portal/index.php?r=bdmep/bdmep.

[36] S. F. Sakagami, S. Laroca, and J. S. Moure, "Wild bee biocoenotics in Sao Jose dos pinhais (PR), South Brazil," Preliminary Report South Zoology, vol. 16, no. 2, pp. 253-291, 1967.

[37] E. F. Morato, "Efeitos da fragmentação florestal sobre vespas e abelhas solitárias na Amazônia Central. II. estratificação vertical," Revista Brasileira de Zoologia, vol. 18, no. 3, pp. 737-747, 2001.

[38] A. V. Ramalho, M. C. Gaglianone, and M. L. D. Oliveira, "Comunidades de abelhas Euglossina (Hymenoptera, Apidae) em fragmentos de Mata Atlântica no Sudeste do Brasil," Revista brasileira de entomologia, vol. 53, no. 1, pp. 95-101, 2009.

[39] D. C. Martins, P. M. C. Albuquerque, F. S. Silva, and J. M. M. Rebêlo, "First record of Aglae caerulea (Hymenoptera, Apidae, Euglossini) in Brazilian cerrado east of the Amazon region, Maranhão state, Brazil," Brazilian Journal of Biology, vol. 76, no. 2, pp. 554-556, 2016.

[40] M. L. D. Oliveira and L. A. D. O. Campos, "Preferência por estratos florestais e por substâncias odoríferas em abelhas Euglossinae (Hymenoptera, Apidae)," Revista Brasileira de Zoologia, vol. 13, no. 4, pp. 1075-1085, 1996.

[41] J. Oksanen, F. G. Blanchet, R. Kindt et al., Vegan: Community Ecology Package. $R$ Package Version 1.17-2. R Development Core Team. R: A Language and Environment for Statistical Computing, R Foundation for Statistical Computing, Vienna, Austria, 2010.

[42] R Core Team, R, A Language and Environment for Statistical Computing, R. Foundation for Statistical Computing, Vienna, Austria, 2018, https://www.r-project.org/.
[43] A. E. Magurran, Medindo a Diversidade Biológica. Tradução Dana Moiana Vianna, Editora UFPR, Curitiba, Brazil, 2011.

[44] S. Palma, "Contribución al estudio de los sifonoforos encontrados frente a la costa de Valparaiso Aspectos Ecológicos," in II Simpósio Latino Americano Sobre Oceanografia Biológica, pp. 119-133, Dóriente, Cumaná, Venezuela, 1975.

[45] M. L. T. Buschini, "Species diversity and community structure in trap-nesting bees in Southern Brazil," Apidologie, vol. 37, no. 1, pp. 58-66, 2006.

[46] W. M. D. Aguiar and M. C. Gaglianone, "Euglossine bee communities in small forest fragments of the Atlantic Forest, Rio de Janeiro state, southeastern Brazil (Hymenoptera, Apidae)," Revista Brasileira de Entomologia, vol. 56, no. 2, pp. 210-219, 2012.

[47] R. K. Colwell, EstimateS: Statistical Estimation of Species Richness and Shared Species from Samples, Persistent, USA, 2006, http://viceroy.eeb.uconn.edu/estimates.

[48] P. Dalgaard, ISwR: Introductory Statistics with R. R Package, Springer, Berlin, Germany, 2005.

[49] S. A. N. Pereira and C. S. Sousa, "Levantamento de Fauna de Abelhas No município de Monte carmelo-MG," Revista GeTeC, vol. 4, no. 7, pp. 11-24, 2015.

[50] H. Batalha Filho, D. G. Pereira, L. A. Nunes, and A. M. Waldschmidt, "Inventário da fauna de abelhas (Hymenoptera, Apoidea) em uma área de caatinga da região de Jequié, BA," Journal of Biosciences, vol. 23, 2007.

[51] W. F. C. Gruchowski, J. Iantas, L. Maciel, and D. R. Holdefer, "Inventário da Fauna de Abelhas (Hymenoptera: Apóidea) com a utilização de Armadilha Atrativa e Interceptadora de vôo em flora típica sul paranaense," Biodiversidade Pampeana, vol. 8, no. 1, pp. 25-31, 2010.

[52] J. S. Wilson, T. Griswold, and O. J. Messinger, "Sampling bee communities (Hymenoptera: Apiformes) in a desert landscape: are pan traps sufficient?," Journal of the Kansas Entomological Society, vol. 81, no. 3, pp. 288-300, 2008.

[53] K. A. Gill and M. E. O’Neal, “Survey of soybean insect pollinators: community identification and sampling method analysis," Environmental Entomology, vol. 44, no. 3, pp. 488-498, 2015.

[54] S. Abrahamczyk, P. Gottleuber, and M. Kessler, "Seasonal changes in odour preferences by male euglossine bees (Hymenoptera: Apidae) and their ecological implications," Apidologie, vol. 43, no. 2, pp. 212-217, 2012.

[55] A. Nielsen, I. Steffan-Dewenter, C. Westphal et al., "Assessing bee species richness in two Mediterranean communities: importance of habitat type and sampling techniques," Ecological Research, vol. 26, no. 5, pp. 969-983, 2011.

[56] D. P. Silva, A. C. B. A. Macêdo, J. S. Ascher, and P. De Marco, "Range increase of a Neotropical orchid bee under future scenarios of climate change," Journal of Insect Conservation, vol. 19, no. 5, pp. 901-910, 2015.

[57] G. C. Venturieri and F. A. L. Contrera, "Biodiversidade de Abelhas na Amazônia: Os Meliponíneos e seu Uso na Polinização de Culturas Agrícolas," Embrapa Semi-árido, vol. 249, pp. 22-35, 2012.

[58] A. Ducke, "Die natürlichen Bienengenera Südamerikas. Zoologische Jahrbücher, Abteilung für Systematik," Geographie und Biologie der Tiere, vol. 34, pp. 51-116, 1912.

[59] P. Becker, J. S. Moure, and F. J. A. Peralta, "More about euglossine bees in amazonian forest fragments," Biotropica, vol. 23, no. 4, pp. 586-591, 1991.

[60] J. C. Botsch, S. T. Walter, J. Karubian, N. González, E. K. Dobbs, and B. J. Brosi, "Impacts of forest fragmentation on orchid bee (Hymenoptera: Apidae: Euglossini) communities in the Chocó 
biodiversity hotspot of northwest Ecuador," Journal of Insect Conservation, vol. 21, no. 4, pp. 633-643, 2017.

[61] T. F. Brito, C. C. Phifer, J. L. Knowlton et al., "Forest Reserves and riparian corridors help maintain orchid bee (Hymenoptera: Euglossini) communities in oil palm plantations in Brazil,” Apidologie, vol. 48, no. 5, pp. 575-587, 2017.

[62] A. H. Powell and G. V. N. Powell, "Population dynamics of male euglossine bees in amazonian forest fragments," Biotropica, vol. 19, no. 2, pp. 176-179, 1987.

[63] C. A. Poveda-Coronel, D. Riaño-Jiménez, and J. R. Cure, "Diversity and phenology of wild bees in a highly Disturbed tropical dry forest "Desierto de la Tatacoa", Huila-Colombia," Neotropical entomology, vol. 47, no. 6, pp. 786-790, 2018.

[64] F. S. Silva, "Orchid bee (Hymenoptera: Apidae) community from a gallery forest in the Brazilian Cerrado," Revista de Biología Tropical, vol. 60, pp. 625-633, 2012.

[65] F. S. Silva and J. M. M. Rebêlo, "Population dynamics of Euglossinae bees (Hymenoptera, Apidae) in an early secondgrowth forest of cajual Island, in the state of Maranhão, Brazil," Brazilian Journal of Biology, vol. 62, no. 1, pp. 15-23, 2002.

[66] B. F. Viana and A. M. P. Kleinert, "A community of flowervisiting bees (Hymenoptera: Apoidea) in the coastal sand dunes of northeastern Brazil," Biota Neotropica, vol. 5, no. 2, pp. 1-13, 2005.

[67] F. A. Silveira and M. J. O. Campos, "A melissofauna de Corumbataí (SP) e Paraopeba (MG) e uma análise da biogeografia das abelhas do cerrado Brasileiro (Hymenoptera, Apoidae)," Revista Brasileira de Entomologia, vol. 39, no. 2, pp. 371-401, 1995.

[68] D. W. Roubik, Ecology and Natural History of Tropical Bees, Cambridge University Press, Cambridge, UK, 1989.

[69] M. Lindauer and W. E. Kerr, "Communication between the workers of stingless bees," Bee World, vol. 41, no. 2, pp. 29-41, 1960.

[70] M. D. E. Silva, M. Ramalho, and D. Monteiro, "Diversity and habitat use by stingless bees (Apidae) in the Brazilian Atlantic Forest," Apidologie, vol. 44, no. 6, pp. 699-707, 2013.

[71] C. S. Machado and C. A. L. D. Carvalho, "Abelhas (Hymenoptera: Apoidea) visitantes dos capítulos de girassol no recôncavo baiano," Ciência Rural, vol. 36, no. 5, pp. 1404-1409, 2006.

[72] J. M. M. Rebêlo, M. M. C. Rêgo, and P. M. C. Albuquerque, "Abelhas (Hymenoptera, Apoidea) da região setentrional do Estado do Maranhão, Brasil," in Apoidea Neotropica: Homenagem aos 90 Anos de Jesus Santiago Moure, pp. 265-278, UNESC, Criciúma, Brazil, 2003.

[73] M. L. Oliveira, E. F. Morato, and M. V. B. Garcia, "Diversidade de espécies e densidade de ninhos de abelhas sociais sem ferrão (Hymenoptera, Apidae, Meliponinae) em floresta de terra firme na Amazônia central," Revista Brasileira de Zoologia, vol. 12, no. 1, pp. 13-24, 1995.

[74] G. C. A. Carvalho, L. M. M. Carreira, M. M. C. Rêgo, and P. M. C. Albuquerque, "Nesting habits of centris (Hemisiella) dichrootricha (Hymenoptera: Apidae) in the northern cerrado of Brazil," Revista de Biología Tropical, vol. 64, no. 3, pp. 1041-1056, 2016.

[75] B. F. Viana, F. O. Silva, and A. M. P. Kleinert, "Diversidade e sazonalidade de abelhas solitárias (Hymenoptera: Apoidea) em dunas litorâneas no nordeste do Brasil," Neotropical Entomology, vol. 30, no. 2, pp. 245-251, 2001.

[76] J. M. B. Oliveira-Junior, S. M. Almeida, L. Rodrigues, A. J. Silvério Júnior, and E. J. Anjos-Silva, "Orchid bees (Apidae: Euglossini) in a forest fragment in the ecotone
Cerrado-Amazonian forest, Brazil," Acta Biológica Colombiana, vol. 20, no. 3, pp. 67-78, 2015.

[77] N. F. D. S. Giehl, M. B. X. Valadão, L. S. Brasil et al., "O Efeito do Fogo sobre a Comunidade de Abelhas Euglossini (Hymenoptera: Apidae) em Floresta de Transição CerradoAmazônia (Mato Grosso, Brasil)," EntomoBrasilis, vol. 6, no. 3, pp. 178-183, 2013.

[78] R. C. Peruquetti, L. A. D. O. Campos, C. D. P. Coelho, C. V. M. Abrantes, and L. C. D. O. Lisboa, "Abelhas Euglossini (Apidae) de áreas de Mata Atlântica: abundância, riqueza e aspectos biológicos," Revista Brasileira de Zoologia, vol. 16, no. 2, pp. 101-118, 1999.

[79] S. H. Sofia and K. M. Suzuki, "Comunidades de machos de abelhas Euglossina (Hymenoptera: Apidae) em fragmentos florestais no sul do Brasil," Neotropical Entomology, vol. 33, no. 6, pp. 693-702, 2004.

[80] C. P. Bezerra and C. F. Martins, "Diversidade de Euglossinae (Hymenoptera, Apidae) em dois fragmentos de Mata Atlântica localizados na região urbana de João Pessoa, Paraíba, Brasil," Revista Brasileira de Zoologia, vol. 18, no. 3, pp. 823-835, 2001.

[81] E. J. D. Anjos-Silva, E. Camillo, and C. A. Garófalo, "Occurrence of Aglae caerulea Lepeletier \& Serville (Hymenoptera: Apidae: Euglossini) in the Parque Nacional da Chapada dos Guimarães, Mato Grosso State, Brazil," Neotropical Entomology, vol. 35, no. 6, pp. 868-870, 2006.

[82] E. L. Neves and B. F. Viana, "A fauna de abelhas da subtribo Euglossina (Hymenoptera, Apidae) do Estado da Bahia, Brasil," in Apoidea Neotropica: Homenagem aos 90 Anos de Jesus Santiago Moure, pp. 223-229, Editora UNESC, Criciúma, Brazil, 2003.

[83] J. M. M. Rebêlo and C. A. Garófalo, "Diversidade e sazonalidade de machos de Euglossini (Hymenoptera, Apidae) e preferências por iscas-odores em um fragmento de floresta no sudeste do Brasil," Revista Brasileira de Biologia, vol. 51, no. 4, pp. 787-799, 1991.

[84] W. S. Armbruster and K. D. McCormick, "Diel foraging patterns of male euglossine bees: ecological causes and evolutionary responses by plants," Biotropica, vol. 22, no. 2, pp. 160-170, 1990.

[85] J. M. M. Rebêlo, História natural das Euglossíneas: As abelhas das Orquideas, p. 152, Lithograf Editora, São Luís, Brazil, 2001.

[86] S. R. M. Pedro and J. M. F. Camargo, "Interactions on floral resources between the Africanized honey bee Apis mellifera $\mathrm{L}$ and the native bee community (Hymenoptera: Apoidea) in a natural "cerrado" ecosystem in southeast Brazil," Apidologie, vol. 22, no. 4, pp. 397-415, 1991.

[87] P. M. C. Albuquerque, L. F. Gostinski, M. M. C. Rego, and L. Carreira, "Flores e Abelhas: a interação da tiúba (Melipona fasciculata, Meliponini) com suas fontes florais na Baixada Maranhense," São Luís: EDUFMA, vol. 1, p. 163, 2013.

[88] A. Antonelli, A. Zizka, F. A. Carvalho et al., "Amazonia is the primary source of Neotropical biodiversity," Proceedings of the National Academy of Sciences, vol. 115, no. 23, pp. 6034-6039, 2018.

[89] L. F. Gostinski, G. C. A. Carvalho, M. M. C. Rêgo, and P. M. C. D. Albuquerque, "Species richness and activity pattern of bees (Hymenoptera, Apidae) in the restinga area of Lençóis Maranhenses National park, barreirinhas, Maranhão, Brazil," Revista Brasileira de Entomologia, vol. 60, no. 4, pp. 319-327, 2016.

[90] C. Pinheiro-Machado, F. A. Silveira, P. M. C. Albuquerque et al., "Surveying and monitoring of pollinators in natural landscapes and in cultivated fiels," in Bees as Pollinators in Brazil, pp. 25-37, Holos Editora, Ribeirão Preto, Brazil, 2006. 


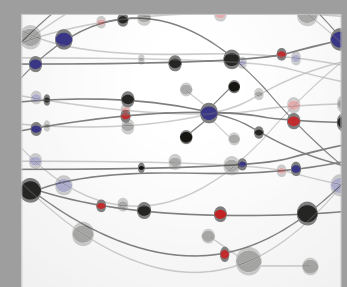

The Scientific World Journal
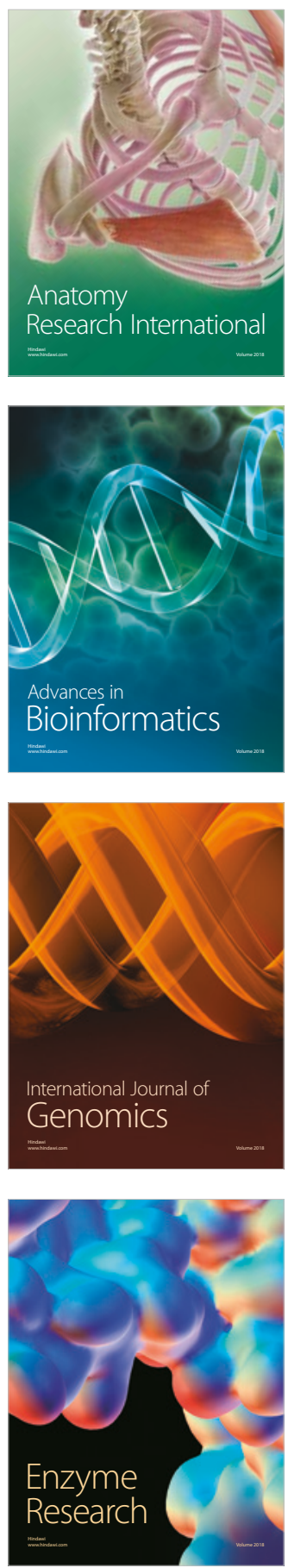
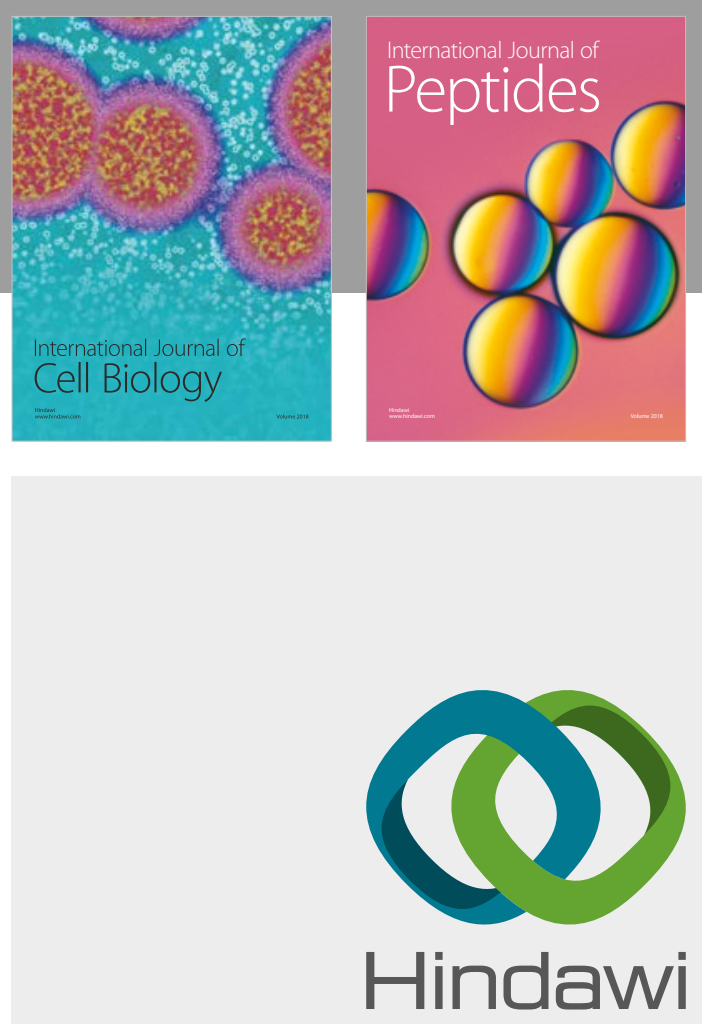

Submit your manuscripts at

www.hindawi.com
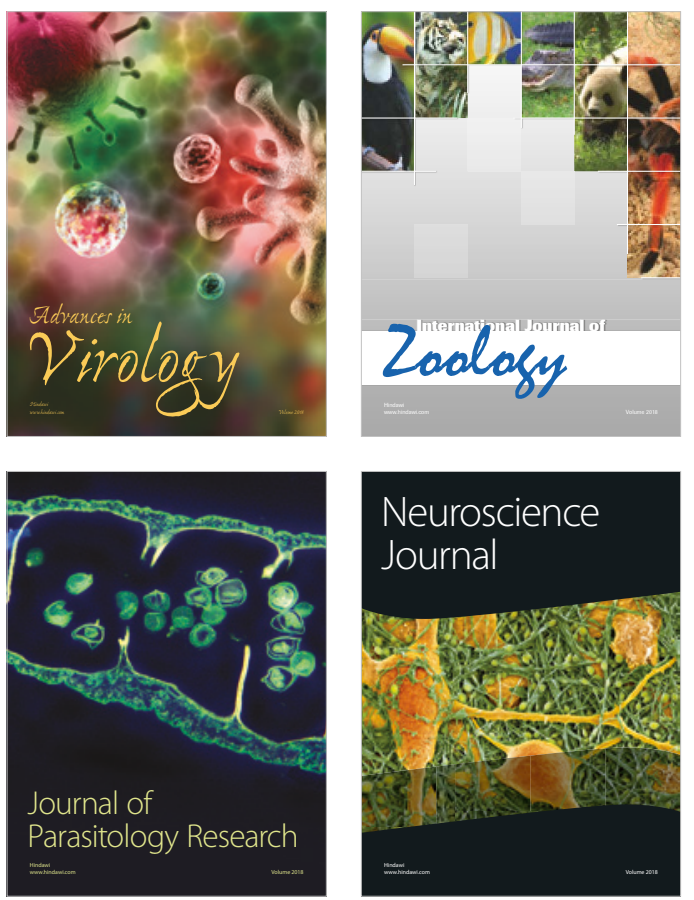
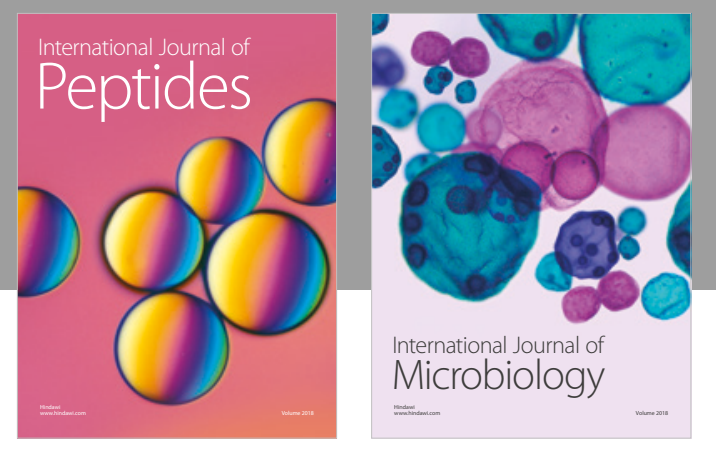

nternational Journal of Microbiology
Journal of
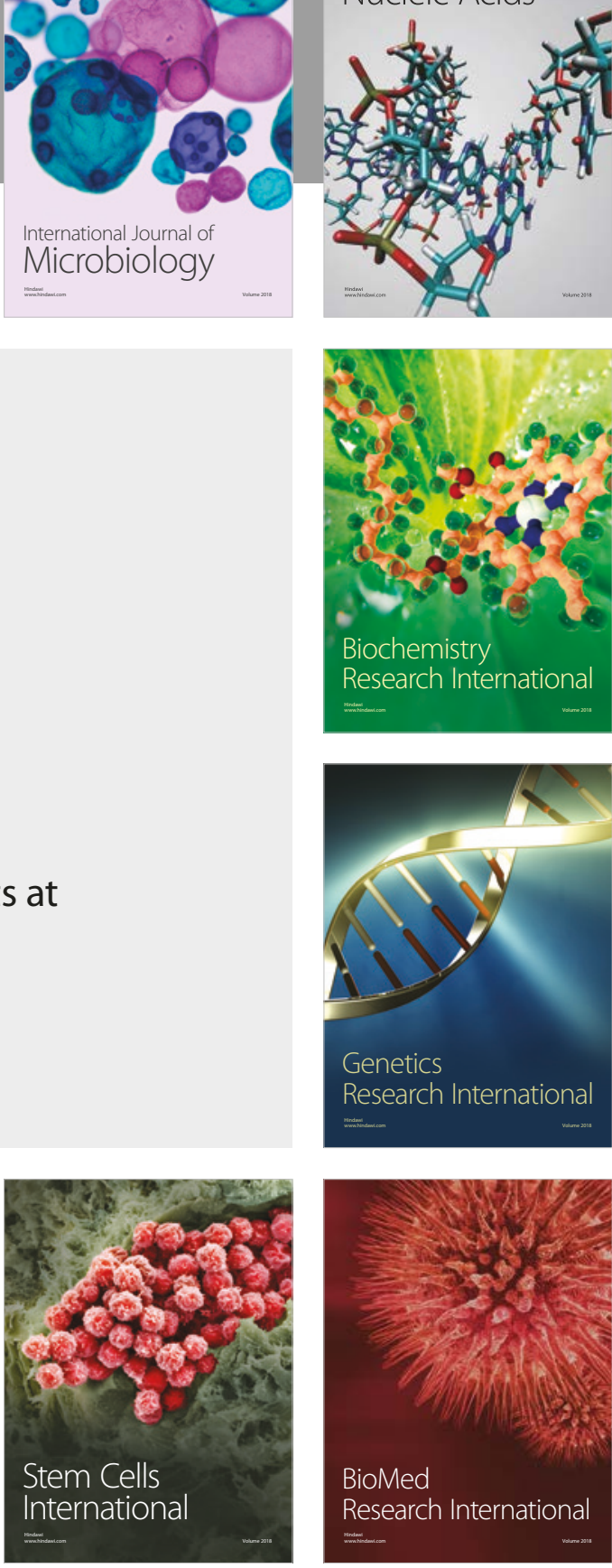
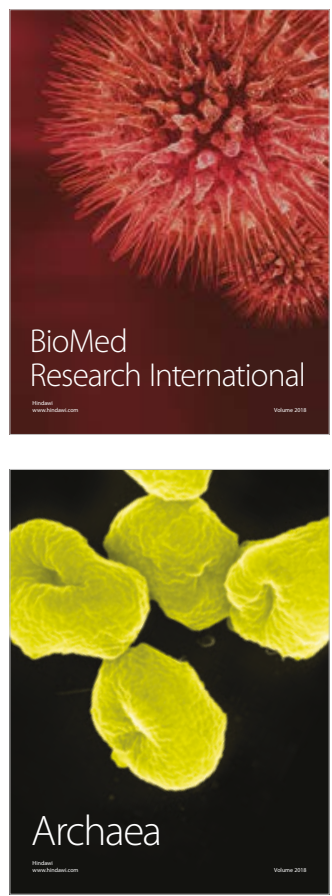